\title{
UM DIA DE REFLEXÕES EM CONFINAMENTO*
}

Antonio Carlos Lopes Petean

Hoje é o vigésimo segundo dia que me mantenho confinado, respeitando uma quarentena que nem todos estão dispostos a cumprir. E ainda na cama, observo da janela do meu quarto a movimentação de pessoas que parecem despreocupadas, ou mal informadas sobre a letalidade de um inimigo que circula entre nós, invadindo corpos sem nos avisar. Acordei cedo, depois de uma noite mal dormida, porque pesadelos me atormentaram. Agora são cinco horas da manhã, e me recuso a sair da cama, pois sinto fortes dores nas costas e uma imensa vontade de dormir durante meses, para não ter que encarar as notícias sobre o número de mortos nas últimas vinte e quatro horas.

Ainda na cama, fico lembrando dos sorrisos, dos gestos e das falas de minhas alunas e alunos e isso me alegra, como me alegra saber que todos estão bem. Não tenho certeza sobre esse "estar bem" que eles me relatam todos os dias, mas assim mesmo procuro me animar e encontrar forças para mais um dia confinado. Infelizmente essa minha felicidade logo se dissipa quando viro para o lado e meus olhos encontram as máscaras que devo usar ao sair de casa na esperança que o inimigo invisível, que atravessou o atlântico, não invada meu corpo e me condene a viver com o medo da morte.

Da janela, observando o circular das pessoas, penso quantos mortos serão necessários para que elas entendam a gravidade da situação. Talvez só compreendam quando os mortos deixarem de serem números e passem a ser corpos e rostos conhecidos e familiares. Ai sim a morte será real e quem sabe se a sabedoria atingirá a todos. Creio que o poeta trágico Ésquilo, na sua obra "Oréstia", nos deixou um aviso ao dizer: "Zeus sem dúvida foi quem levou os homens pelos caminhos da sabedoria e decretou a regra para sempre certa: O sofri-

${ }^{*}$ DOI - 10.29388/978-65-86678-07-9-0-f.29-34 
mento é a melhor lição". Mas não sei dizer se essa máxima se aplica aos meus conterrâneos.

Nesse vigésimo segundo dia que sigo confinado, sem fazer a barba, sem vontade de escovar os dentes, sem cortar o cabelo e sem me ocupar em pensar no outro, pois ele já não existe, e ainda na cama, in vento o que fazer. Então me levanto, vou para a cozinha, frito um ovo e volto para cama. É o vigésimo segundo dia que sigo confinado e sigo pensando como distrair esse sofrimento que às vezes busco ignorar, ou negar, ou intensificá-lo, como uma forma de extirpá-lo de forma rápida. Mas eu sigo angustiado e sigo negando qualquer possibilidade de outras vidas. E como adoro um bom vinho e adoro olhar aqueles olhos que me seduziram eu continuo com meu autoconfinamento na esperança de um retorno a displicente "normalidade" do real.

Na cama, novamente começo a ler as últimas notícias, me ponho a refletir sobre elas, e as relaciono ao contexto que arrasa os mais duros corações e as mentes mais sadias. Penso que o tempo de confinamento e a solidão que ele escancara pode causar sérios prejuízos psíquicos a determinadas pessoas. Não apenas o tempo, mas as notícias que recebemos nesses dias também podem causar uma avalanche mental. E são algumas dessas notícias que me levaram a refletir sobre o "gerenciamento" da pandemia e da situação sanitário do país que agora é dirigido por liberais que possuem a clara intenção de destruir o Estado, criando um vazio e um caos que afetará principalmente as classes menos favorecidas.

Nesse vigésimo segundo dia do meu confinamento começo minhas reflexões a partir do autoritarismo que reina no ministério da educação e, também, reflito sobre a falta que faz um certo romantismo "revolucionário".

O autoritarismo é a marca reinante dos movimentos e regimes fascistas que sempre elegem um inimigo para odiar. Os regimes autoritários de contornos fascistoides possuem seus inimigos e contra eles liberam o sentimento de ódio. Historicamente os inimigos odiados pelos fascistas sempre foram, são e serão os artistas, os cientistas, os inte- 
lectuais, os professores, os jornalistas e, também, muitas iniciativas populares classificadas como "esquerdistas" como a livre escolha dos reitores das instituições de ensino. E o ministério da educação deu demonstração desse autoritarismo fascista ao ignora uma determinação da justiça para que o candidato escolhido pela comunidade acadêmica do IFRN fosse empossado.

Mas o MEC se recusou e não deu posse ao reitor eleito pela comunidade, e o interventor nomeado pelo ministério da educação permaneceu no cargo, pouco se importando com a justiça. Ou melhor, o MEC seguiu afrontando a justiça. Além dessa afronta, o desmatamento da Amazônia atingiu recorde em abril de 2020 e o Ministro do meio ambiente exonerou o diretor de proteção ambiental do IBAMA e ao mesmo tempo anulou multas de madeireiros e concedeu anistia aos desmatadores da mata atlântica. E estamos apenas no vigésimo segundo dia da quarentena e o "inominável" que ocupa a cadeira de presidente nomeia um novo diretor da polícia federal, que ao assumir interfere na direção da polícia federal no estado do Rio de Janeiro. Inúmeras questões poderiam ser levantadas aqui. Então uma rápida reflexão.

Não concordo com a ideia de que o atual governo é um desgoverno. Para mim, esse governo administra a pandemia a seu favor. Ao incentivar as pessoas a saírem das suas casas, ao pedir a reabertura da economia e ao promover aglomerações, ele contribui para consolidar a sua fala inicial sobre a COVID ("é uma gripezinha"). Com isso a quarentena cai, o vírus agradece, e a contaminação continuará. Portanto, não haverá pico e nem achatamento da contaminação como nos demais países da comunidade europeia. E ele, o inominável, sabe que aqueles que fazem oposição ao seu governo, estão de quarentena e isso torna as ações das oposições limitadas as redes sociais.

Outra ação desse governo foi eliminar o rastreamento de armas e não preciso dizer quem isso favorece. Voltando ao Ministério da educação, eu só tenho a lamentar que o Sr. Ministro tenha resolvido pela manutenção da data do ENEM, mesmo sabendo da paralisação 
das escolas que seguem a quarentena conforme as orientações sanitárias. Mas o ministro sabe que isso afetará as cotas raciais e sociais. Por isso, que para mim, o atual governo administra a crise sanitária incentivando, implicitamente, as pessoas a saírem, embora alguns membros do seu governo digam o contrário. Ao mesmo tempo leio artigos e comentários que refletem sobre um possível fim do capitalismo.

Talvez essa seja uma aposta ou previsão um tanto arriscada. A pandemia demonstrou ou descortinou as graves contradições do capitalismo, que muitos na academia já sabiam, mas que não tenho certeza se a massa trabalhadora tem está mesma percepção, mesmo com a pandemia mostrando e revelando essas contradições. Podemos dizer que o capitalismo está balançando, que o muro capitalista está abalado sim, mas quem dará o empurrão que fará desabar esse muro. No caso do Brasil o projeto que esse governo representa está se aprofundando e ao mesmo tempo me parece "possível" que ele consiga construir um estado extremamente repressor (e esse é o seu desejo).

O que vou dizer não é uma ironia, não é uma crítica e reconheço que o medo é o sentimento que nos mantém vivos, que nos permite a realização dos nossos projetos individuais e coletivos. Todos temos medo e isso é algo inegável. Mas as revoluções que ocorreram na História, seja ela a francesa, a russa, a chinesa, a cubana, os homens que participaram não temeram a morte. Talvez não existam mais românticos revolucionários. Quero dizer que os românticos foram altruístas e não temeram a proximidade da morte.

Hoje, quem não teme a morte são alguns fascistas que se aglomeram, treinam, reverenciam o "presidente", agridem enfermeiras, fazem passeatas, fazem carreatas e ajudam esse governo a dar continuidade ao seu projeto de destruição do Estado e das conquistas sociais. Por outro lado, existem aqueles que desejam a queda desse governo e do modelo que ele está impondo. E esses que deveriam estar nas ruas manifestando sua indignação e insatisfação com esse governo, temem um inimigo invisível que é real e muito letal. Nem falarei dos negacio- 
nistas que fazem parte da base social de apoio desse governo. Esses seguem e seguirão negando a ciência e a esfericidade do planeta.

Terminarei essa reflexão dizendo que nesse vigésimo segundo dia de quarentena eu confesso que tenho medo, que compartilho do medo de todos que seguem de quarentena. Acredito que nesse momento o medo seja o único sentimento que deve ser socializado e talvez seja a única "coisa” a ser socializada por enquanto, não sei. Não tenho intuito de criticar o confinamento, porque aposto nele, mas percebo que estamos diante de uma biopolítica de viés extremamente fascistóide e neoliberal, e nossas armas são limitadas. Só me resta escrever lamentando a destruição das conquistas sociais, da Amazônia, da Mata Atlântica, do Cerrado, dos povos nativos, do sistema de saúde e das Universidades Públicas.

Desejo e clamo para que continuem de quarentena, enquanto eu sigo me recusando a acreditar que tudo isso passará logo e que seremos diferentes, e isso quer dizer que a espécie será menos egoísta e menos voraz. São dias de angústia e saudade. Saudade!!!!!! Palavra imortalizada pelos portugueses que se lançaram as grandes navegações sem a certeza da volta. Tenho muita saudade, mas não sou português e sou teimoso, então, espero os muitos reencontros. Desejo que se cuidem. Então até amanhã com o vigésimo terceiro dia dessa quarentena que salvará vidas. 
